\title{
Frontier on the Water: Conflict and Interaction of Balkan-Black Sea Shipbuilding Traditions of the $16^{\text {th }}$ and $18^{\text {th }}$ Centuries
}

\author{
Viacheslav Sarychev ${ }^{1}$ 우
}

'Corresponding author/Sorumlu yazar: Viacheslav Sarychev (Senior Researcher), Zaporizhzhia National University, Faculty of History, Department of Source Studies, Historiography and Special Historical Disciplines, Khortytsia National Reserve, Zaporizhzhia, Ukraine.

E-posta: svdsich@gmail.com ORCID: 0000-0002-3176-878X

Submitted/Başvuru: 15.09.2020 Revision Requested/Revizyon Talebi: 15.11.2020

Last Revision Received/Son Revizyon:

15.11.2020

Accepted/Kabul: 27.01.2021

Citation/Atıf: Sarychev, Viacheslav, "Frontier on the Water: Conflict and Interaction of Balkan-Black Sea Shipbuilding Traditions of the $16^{\text {th }}$ and $18^{\text {th }}$ Centuries", Güneydoğu Avrupa Araştırmaları Dergisi, 35 (2020), s. 35-42. https://doi.org/10.26650/gaad.795289

\begin{abstract}
The article considers the directions of mutual influence of shipbuilding traditions in the Black Sea basin and in the area of the European frontier of the $16^{\text {th }}-18^{\text {th }}$ centuries, the process of evolution of specific shipbuilding forms. The article is based on written evidence of the $16^{\text {th }}-17^{\text {th }}$ centuries, research results of documents of the Ottoman Empire, archival documents and printed documents on the history of the Russian fleet of the $18^{\text {th }}$ century, archeological data, reference books on shipbuilding of the Age of Sail. It is proved that as a result of mutual influence, the Ottoman Empire increased the use of small river and sea vessels. In particular, these were Ottoman chaikas that protected the mouths of the Danube and Dnipro against the Cossacks raids. On the other hand, the Danube saikas and Cossacks chaikas evolved in the direction of increasing their artillery power and versatility due to the confrontation with Ottoman ships. This mutual influence took place in the conditions of permanent militarization of the life of the European frontier. However, it was positive, because it stimulated the development of various sectors of the economy of the countries and peoples of the European frontier. Keywords: Frontier, Chaika, Cossacks, Evolution of Shipbuilding, Mutual Influence of Shipbuilding Traditions
\end{abstract}




\section{Introduction}

The reverse side of the growth of power of the Ottoman Empire in the 15th-16th centuries was a permanent military tension at the borders, in particular in the area of the Eastern European frontier. Moreover, the confrontation of different societies continued on land and on water. Sporadic attacks of Zaporozhzhya Cossacks on vessels in the territories controlled by the Crimea and the Ottoman Empire took place in the 15th century. In particular, the clash near Tyagin in 1492. The attacks had intensified in 1538, when the Ottomans captured the lower reaches of the Dniester and Dnipro. A similar situation had developed on the Danube border, where military confrontation had also taken place with the use of ships. Gradually, the militarization of border life had become one of the factors in the development of shipbuilding from the Danube to the eastern shores of the Black and Azov Seas.

The history of this frontier has been widely covered in the scientific literature of various countries. The issues of shipbuilding in the frontier are covered in some way in the works of V. Ostapchuk (USA), R. Gradeva (Bulgaria), V. Milchev (Ukraine) and others. However, the available data need to be supplemented and systematized. The purpose of this study is to outline the mutual influence of shipbuilding traditions in the Black Sea basin during the military confrontations of the 16 th - 18th centuries. To do this, it is necessary to determine the signs of such an impact on the evolution of shipbuilding of the Countries of the Danube River Basin, the Ottoman Empire and the Zaporozhzhya Cossacks by descriptive and comparative methods.

The relevance of this is due to the place of shipbuilding in the history of any country. It has always been the most modern way of transportation for its time which embodied the latest advances in materials processing, navigation, geography, labor organization, martial arts, security, logistics and more. Therefore, it can be considered one of the signs of the cultural level of society, which is provided by the experience of many generations, a kind of civilizational tradition. This study was carried out within the grant program of the Shevchenko Scientific Society on Ukrainian Studies in the United States.

The dominance of the Ottoman Empire in the Black Sea was ensured

thanks to a powerful fleet. It consisted of two parts. The bases were galleys, kalyats, galleons, etc. They were used in battles at the sea and coast. However, this was not enough for further advance by land and to control the territories.

The second part of the fleet consisted of small vessels for reconnaissance, transportation of goods and participation in battles. These narrow and long sailing vessels of river and coastal navigation were generally inherent in the shipbuilding of the Mediterranean and Black Sea basins. Due to numerous tasks, they have acquired numerous variations - from a cargo river-sea vessel to a luxurious and expensive boat to serve the sultan's harem. One of such boats is on display at Istanbul's Maritime Museum. Despite the functional diversity, these vessels had a single name. This is probably due to the general similarity of the design. The 
name of these vessels "saika" (Turk. "sayqa") was used in different languages with a specific pronunciation for each of them.

\section{Danube Front Line}

In particular, that was the Danube saika, or shaika (hun. "sajka"). These boats evolved significantly, as the militarization of the Danube border had led to the development of military shipbuilding. The forerunner of saika can be considered the Hungarian river pinas (hun. "naszad") - a light warship, which probably originated under German influence in the late 15th century. It had an oblique sail and towing straps. Together with the bowsprit and steering wheel, its length reached 24 meters. A special feature were two storage cabins - on the bow for the gunner with a light gun, and on the stern for the skipper ${ }^{1}$.

Undecked saikas (8 - $15 \mathrm{~m}$ long) were used by the Ottoman army on the Danube and the Black Sea for transportation of goods and in military affairs during the 16th - 18th centuries 2. There were also larger saikas up to $25 \mathrm{~m}$ long. Their garrison consisted of 18-24 rowers, twenty soldiers, and a skipper ${ }^{3}$. At the beginning of the Austro-Turkish War of $1566-1568$, the armed shallow rowing clinker built saikas with a capacity of 35-40 soldiers, were used in the attack of Suleiman the Magnificent's army of 100,000. For the same purpose, a number of shipbuilding centers were established on the Danube and its tributaries. About 400 ships were built in the Serbian town of Smederevo, Bulgarian Vidin and Ruse. In addition to these transport saikas, the other transport vessels were built, including palandaria. The ships were also built in other cities controlled by the empire - Krusevac (Serbia), Zvorin (Bosnia), Pozega (Slovenia), Nikopol (Greece) ${ }^{4}$. The active use of small river transport vessels, according to the Bulgarian researcher R. Gradeva, actualizes the question of local shipbuilding traditions, which the empire inherited with the advent in the Balkans ${ }^{5}$.

This is evidenced, in particular, by the clinker fastening of the planking on these saikas, which is typical of medieval technology. At the same time, the researcher emphasizes the Ottoman Empire's repercussions on the peoples of the peninsula: "The river also brought war and borders closer to the Balkans, helping to militarize the local society, which mostly lived according to border laws, always ready to defend and attack. During the war with the Holy League at the end of the 17th century, this proximity strongly influenced the local population" 6 .

1 Lásló Veres, Richard Woodman, Unter Segeln, Vom Einbaum zum Hightech-Segler, Delius Klasing 2002, s. 125.

2 Victor Ostapchuk, Olexander Galenko. “Kozacki chornomorski pohody u morskiy istorii Kiatiba Chelebi “Dar velykyh muzhiv u vouvanni moriv", Mappa Mundi, Lviv - Kyiv - New York 1996, s. 354.

3 İdris Bostan. "Gemi Yapımcılığı ve Osmanlı Donanmasında Gemiler". Türk Denizcilik Tarihi 1. Başlangıçtan XVII. Yüzyılın Sonuna Kadarl, Istanbul 2009, s. 334.

4 Rossitsa Gradeva, "War and Peace along the Danube: Vidin at the End of the 17th Century", Oriente Moderno. Nuova serie, 2001, Anno 20 (81), № 1, p. 163.

5 Gradeva, ibid., p. $162-164$.

6 Gradeva, ibid., p. 174. 
This affected all areas of its life and, in particular, shipbuilding. In the 17th century the traditional Danube pinas became longer, lower and received the Turkish name "saika". However, the renaming could have taken place under the influence of the Italian "sajetta" or the Ukrainian "chaika". In the 18th century, as a result of specialization, the half-saika, full saika, double saika and other varieties appeared. The $12 \mathrm{~m}$ half-saika had low freeboard, shallow draft, two light half-pound guns on the bow and stern, slanted sail, protective shield, towing straps, and up to nine pairs of oars. The double-saika reached $27.5 \mathrm{~m}$, had towing straps, two masts with a square sails, which were used as auxiliary, one gun at the bow and six in the sides with gunports?

Since the 60's of the 18th century the saika evolved into the Serbian sailing and rowing vessels. During the fight against the Ottoman Empire, they were used by Serbian border guards and Zaporozhzhya Cossacks, who served the Austrian Empire. These ships were characterized by the peculiar naval architecture of that period (transom, bowsprit). This direction of evolution had a distinct universality. Their purpose was to transport soldiers and cargo, guide and protect crossings, patrol, fight with small enemy vessels with the help of 6 - 8 light guns on "big chaikas" or 2 - 4 guns on "half-chaikas" ${ }^{8}$. The universality is also emphasized by the development of sailing rigging.

\section{Black Sea Frontier Zone}

Perhaps the first mention of a Cossack ship under its classic name is recorded in the Polish "Chronicle of Martin Bielski" of the 16th century. It describes the overcoming of the Dnipro rapids by the Cossack "The Cossacks usually overcome the rapids in their leather boats, which they call chaikas (pol. czajki) by taking them downstream and upstream with ropes. According to Greek historian Zonara, the Rus harmed the Greek Caesars in such boats reaching Constantinople from time to time" ". Given that the author died in 1576, this information should be attributed to the date of his death or even to the middle of the century. This is confirmed by the Austrian historian Engel, who connects the beginning of the construction of leather chaikas with the Cossack leader Prince Dmytro Vyshnevetsky ${ }^{10}$ who built a fortification of the Cossack headquarters on the Dnipro island of Mala Khortytsia in 1554.

Thus, the very first mention of the chaika indicates a characteristic feature of Cossack shipbuilding - the creation of universal river and sea vessels with features of succession from ancient Rus times. The occasional use of light leather vessels at sea in the coastal strip cannot be completely ruled out. However, long naval campaigns required stronger vessels. These were the chaikas described in later sources.

7 Veres, Woodman, ibid., s. 125.

8 Volodymyr Milchev, Zaporozhcy na Viyskovomu Kordoni Avstriyskoi Imperii, 1785 - 1790, Zaporizhzhia: Tandem-U 2007, s. 41, 61, 62, 74, 76.

9 Kronika Marcina Bielskiego, III, Sanok 1856, s. 1359.

10 logan-Hristian Engel, Istoria Ukrainy ta ukrainskih kozakiv, Harkiv: Fakt 2014, s. 106. 
In the 30's of the 17th century d'Ascoli wrote about long hollowed and well-armed chaikas (saiche): "long chaikas, like frigates" ". Beauplan described in detail the process of constructing such boats by hollowing-out of the wood and clinker planking. The Cossacks inherited this method of attachment from the Vikings. In contrast, the Ottoman ships used carvel planking (the planks were laid edge to edge). The Cossack boat had an equally pointed bow and stern, two oars for control on the bow and stern, a layer of brushwood on the sides, 10 - 15 pairs of oars, $4-6$ guns, length up to $20 \mathrm{~m}$. The ratio of length and width reached a value about $5-6$ times. The garrison consisted of more than 50 soldiers. The sail played a supporting role ${ }^{12}$. Thus, the Cossack chaika was a universal transport and combat vessel for transporting troops, conducting landings, boarding, raids and more. Flotillas of chaikas comprising several dozen and hundreds of ships began to operate in the Black Sea. The Ottomans often used the name "şayka" for them, which could be the name of similar vessels used by the Turks in particular on the Danube ${ }^{13}$.

The superiority of the Cossacks chaikas over the galleys in speed, maneuvering ability and action on river and sea shoals was the reason for combat use of such vessels in the Ottoman fleet. Their widespread use was carried out in areas that were dangerous because of the Cossacks threat. It is known about 60 vessels that gathered to defend the Danube and the sea coast in 1614-1615, and the flotilla of "Kiliya" and "Ackerman" chaikas that defended the mouth of the Dnipro in $1621^{14}$. It was significant that these were not only captured from the Cossacks, but also specially built vessels. Regarding their characteristics, V. Ostapchuk and O. Galenko wrote: "We can assume that the Ottoman chaika was an imitation of a Cossack chaika (or at least they borrowed a lot of its combat features from the Cossacks), with some of its advantages - maneuverability and ability to float in shallow waters of rivers and sea coasts, and by the sea (but there is no evidence that the Ottomans tied their chaikas with reeds for buoyancy, as did the Cossacks..." ${ }^{15}$. Taking into account the high level of shipbuilding of the Ottoman Empire, probably the "Ottoman chaikas" for the Black Sea had planked framing and were fastened edge to edge. This, in turn, could not remain unnoticed by the Cossacks, who at that time made their boats on the basis of dugouts with clinker planking.

At the end of the 17th century the Moscow Empire gradually joined the competition for supremacy at the Black Sea. In the 30's of the 18th century Russian Field Marshal Burkhard Christoph Graf von Münnich recognized the Cossack boat called "dub" as the most suitable for sailing across the rapids. His schematic drawing depicted a keel at the base of the ship instead of the dug-out known from d'Ascoli and Beauplan descriptions ${ }^{16}$.

11 "Opisanie Chernogo moria i Tatarii, sostavil dominikanec Emiddio Dortelli d 'Askoli, prefect Kaffy, Tatarii i proch. 1634", Zapiski Odesskogo obshestva istorii i drevnostei, Odessa 1902, v. XXIV, ch. 2, Materialy, s. 97 - 98.

12 Giliom Lavasser de Boplan, Opisanie Ukrainy, Moskva: Drevlehranilishe 2004, s. 257 - 259.

13 Victor Ostapchuk, "Five documents from the Topkapi palace archive on the Ottoman defense of the Black Sea against the Cossacks", Journal of the Turkish Studies, Washington 1987, V. XI, s. 49.

14 Ostapchuk, Galenko, ibid., p. 351, 357.

15 Ostapchuk, Galenko, ibid., p. 354.

16 RGADA, f. 248 Pravitelstvuushi senat, op. 1, d. 558. 
This testifies in favor of the spread of planked ships building in Zaporozhzhya. Its beginning can be attributed to the last decades of the 17th century. This period is considered to be the time of the appearance of the Cossack boat "dub" (after the material dub (eng. oak) ${ }^{17}$. The quality of this wood allowed it to replace the hollowed wood in its base with a lighter keel without reducing the strength of the boat.

During the 18th century Zaporozhzhya Cossacks worked in state-owned shipyards and constructed the planked ships. In particular, the "novomanirna Cossack boats"built at the Zaporozhzhya shipyard during the Russian-Turkish War of 1736-1739. The underwater archeological research and reconstruction of one of such boats raised from the Dnipro bottom near the island of Khortytsia in 1999 prove its resemblance with the Cossack chaikas of the previous century ${ }^{18}$. Another example are the "Zaporozhzhya boats" of the Kremenchug shipyard of $1787-1791^{19}$. They are also identical in size, proportions, purpose and even names. However, due to the increase of combat missions, "Zaporozhzhya boats" took a separate place. To counter the Ottoman fleet of battleships, they were equipped with 18 - 30 pounder guns. ${ }^{20}$ As a result, the Cossack variety of gunboat appeared, which became the first such ship in the fleet of the Russian Empire.

Thus, the interaction of different shipbuilding traditions was inherent in the initial stage of creation of the Russian Black Sea Fleet. However, it was not limited to the participation of Ukrainians. This is proved in particular by the data about the construction of Kirlangichs - sailing-rowing artillery vessels of Mediterranean origin 25-30 m long at the Kremenchug shipyard. They were built by other bearers of shipbuilding traditions who arrived from Kherson, namely 19 Greek carpenters, 11 Turkish carpenters, 6 Turkish blacksmiths and 20 other Turkish workers commanded by an ensign of Greek descent ${ }^{21}$.

\section{Conclusion}

In general, one may argue for various forms of mutual influence of shipbuilding traditions. The main direction of evolution of the Danube saika of the 16th-18th centuries was the development of cannon armament. It arose as a result of the Ottoman Empire's advance up the river and the creation of its shipbuilding infrastructure there. In fact, the answer was the Danube specialized ships with heavy and light guns such as Ottoman galleys. Also, the universal multitask transport and combat boats with 6-8 light guns became widespread.

The confrontation highlighted the need for small vessels such as saika for various purposes of the Ottoman fleet. On the Danube, such vessels of local origin began to be

17 Tatiana Zhavzharova, “Nazvy richkovo-morskyh suden Zaporzkyh kozakiv”, Visnyk Zaporizkogo Derzhavnogo Universitetu : Zbirnyk naukovyh statei. Fililogichni nauky, Zaporizhzhya 1999, № 1, s. 45.

18 Dmitry Kobalia, Valery Nefiodov, "Zaporozka chaika": istoria odniei znahidky, Zaporizhzhia: Dyke pole 2005, s. 138.

19 DAMO, f. 243 Fond stroenia goroda Nikolaeva, op. 1, spr. 2.

20 Materialy dlia istoirii russkogo flota, XV, Sankt-Peterburg 1901, s. 86, 123, 213, 228.

21 DAMO, f. 243 Fond stroenia goroda Nikolaeva, op. 1, spr. 29. 
traditionally used for transportation. On the other hand, the need for military action prompted the Sultan's administration to construct a number of new shipbuilding centers on the Danube, specializing in transport ships. In the Northern Black Sea region, the superiority of the Zaporozhzhya chaikas in maneuverability and speed stimulated the emergence of similar chaika fighters, or "Ottoman chaikas".

The clash of the Zaporozhzhya Cossacks with the Ottoman fleet stimulated the improvement of chaikas. They received cannon armament, plank construction, means of protection and stabilization on sea waves, etc. This allowed to expand the geography of the use of chaika flotillas, which became a powerful naval force. In the 18th century The Ottoman battle fleet directly influenced the further development of chaikas, resulting in the appearance of the "Zaporozhzhya boat" of the Black Sea Cossacks, in fact the Kozak version of the gunboat.

Thus, the mutual influence affected the shipbuilding of almost all major participants of the conflict on the European frontier. Unfortunately, this took place in a fierce and destructive struggle. However, the development of shipbuilding stimulated related industries, required new knowledge, advanced training for workers and more. One way or another, it contributed to the general development of the countries and peoples of the European frontier. These examples are also the guidelines for determining areas for further research.

Peer-review: Externally peer-reviewed.

Conflict of Interest: The author has no conflict of interest to declare.

Grant Support: The author declared that this study has received no financial support.

Hakem Değerlendirmesi: Dış bağımsız.

Çıkar Çatışması: Yazar çıkar çatışması bildirmemiştir.

Finansal Destek: Yazar bu çalışma için finansal destek almadığını beyan etmiştir.

\section{Bibliography}

\section{Archival Sources}

Derzhavny arhiv Mykolaivskoi oblasti (DAM0), f. 243 Fond stroenia goroda Nikolaeva, op. 1, spr. 2, spr. 29. Rosiisky gosudarstveny arhiv davnih aktiv (RGADA), f. 248 Pravitelstvuushi senat, op. 1, d. 558.

\section{Books and Articles}

Віктор Остапчук, Олександр Галенко, “Козацькі чорноморські походи у морській історіі Кятіба Челебі. “Дар великих мужів у воюванні морів”, Mappa Mundi, Львів - Київ - Нью-Йорк 1996.

Володимир Мільчев, Запорожчі на Військовому Кордоні Австрійської імперії, 1785 - 1790, Запоріжжя: Тандем-У 2007.

Дмитро Кобалія, Валерій Нефьодов, “Запорозька чайка” : історія однієї знахідки, Запоріжжя : Дике поле 2005. 
Frontier on the Water: Conflict and Interaction of Balkan-Black Sea Shipbuilding Traditions of the...

Гильйом Лавассер де Боплан, Описание Украины, Москва: Древлехранилище 2004.

Материалы для истории русского флота, т. XV, Санкт-Петербург 1901.

Йоганн-Християн Енгель, Історія України та українських козаків, Харків: Факт 2014

“Описание Черного моря и Татарии, составил доминиканец Эмиддио Дортелли д'Асколи, префект Каффы, Татарии и проч. 1634”, “Записки Одесского общества истории и древностей”, т. XXIV, ч. II, Материалы, Одесса 1902.

Тетяна Жавжарова, “Назви річково-морських суден Запорозьких козаків”, Вісник Запорізького державного університету: Збірник наукових статей. Філологічні науки, Запоріжжя 1999, № 1.

Dmitry Kobalia, Valery Nefiodov, "Zaporozka chaika": istoria odniei znahidky, Zaporizhzhia: Dyke pole 2005.

Giliom Lavasser de Boplan, Opisanie Ukrainy, Moskva: Drevlehranilishe 2004.

İdris Bostan. "Gemi Yapımcılığı ve Osmanlı Donanmasında Gemiler”. Türk Denizcilik Tarihi 1. Başlangıçtan XVII. Yüzyılın Sonuna Kadarl, Istanbul 2009.

logan-Hristian Engel, Istoria Ukrainy ta ukrainskih kozakiv, Harkiv: Fakt 2014.

Kronika Marcina Bielskiego, III, Sanok 1856.

Lásló Veres, Richard Woodman, Unter Segeln, Vom Einbaum zum Hightech-Segler, Delius Klasing 2002.

Materialy dlia istoirii russkogo flota, t. XV, Sankt-Peterburg 1901.

"Opisanie Chernogo moria i Tatarii, sostavil dominikanec Emiddio Dortelli d 'Askoli, prefect Kaffy, Tatarii i proch. 1634", Zapiski Odesskogo obshestva istorii i drevnostei, t. XXIV, ch. II, Materialy, Odessa 1902.

Rossitsa Gradeva, "War and Peace along the Danube: Vidin at the End of the 17th Century", Oriente Moderno. Nuova serie, 2001, Anno 20 (81), № 1.

Tetiana Zhavzharova, "Nazvy richkovo-morskyh suden Zaporozkskih kozakiv", Visnyk Zaporizkogo Derzhavnogo Universitetu : Zbirnyk naukovyh statei. Fililogichni nauky, Zaporizhzhya 1999, № 1.

Victor Ostapchuk, "Five documents from the Topkapi palace archive on the Ottoman defense of the Black Sea against the Cossacks", Journal of the Turkish Studies, Washington 1987, V. XI.

Victor Ostapchuk, Olexander Galenko, "Kozacki chornomorski pohody u morskiy istorii Kiatiba Chelebi "Dar velykyh muzhiv u vouvanni moriv", Mappa Mundi, Lviv - Kyiv - New York 1996.

Volodymyr Milchev, Zaporozhcy na Viyskovomu Kordoni Avstriyskoi Imperii, 1785 - 1790, Zaporizhzhia: Tandem-U 2007. 